Article

\title{
Experimental Campaign of a Low-Cost and Replaceable System for Passive Energy Dissipation in Precast Concrete Structures
}

\author{
Álvaro Mena ${ }^{1, *}$, Jorge Franco ${ }^{2}$, Daniel Miguel ${ }^{2}$, Jesús Mínguez ${ }^{1}$, Ana Carla Jiménez ${ }^{2}$, \\ Dorys Carmen González ${ }^{1}$ and Miguel Ángel Vicente ${ }^{1}$ (1) \\ 1 Department of Civil Engineering, University of Burgos, 09001 Burgos, Spain; jminguez@ubu.es (J.M.); \\ dgonzalez@ubu.es (D.C.G.); mvicente@ubu.es (M.Á.V.) \\ 2 ICONKRETE 2012, S.L., 28035 Madrid, Spain; jorge.franco@iconkrete.com (J.F.); \\ daniel.miguel@iconkrete.com (D.M.); ana.jimenez@iconkrete.com (A.C.J.) \\ * Correspondence: amena@ubu.es; Tel.: +34-947-259423
}

Received: 29 December 2019; Accepted: 7 February 2020; Published: 11 February 2020

\begin{abstract}
This research develops a new low-cost energy dissipation system, capable of being implemented in residential structures in developing countries with high seismic activity, in which the current solutions are not economically viable. These residential structures are entirely made of precast concrete elements (foundations, walls, and slabs). A solution is developed that consists of a new connection between a precast foundation and a structural wall, which is capable of dissipating almost all the seismic energy, and therfore protecting the rest of the building from structural damage. To validate the solution, a testing campaign is carried out, including a first set of "pushover" tests on isolated structural walls, a second set of "pushover" tests on structural frames, and a final set of seismic tests on a real-scale three-storey building. For the first and second set of tests, ductility is analyzed in accordance with ACI 374.2R-13, while for the third one, the dynamic response to a reference earthquake is evaluated. The results reveal that the solution developed shows great ductility and no relevant damage is observed in the rest of the building, except in the low-cost energy dissipation system. Once an earthquake has finished, a precast building implemented with this low-cost energy dissipation system is capable of showing a structural performance level of "immediate occupancy" according to ACI 374.2R-13.
\end{abstract}

Keywords: seismic test; pushover test; precast concrete structure; shake table

\section{Introduction}

Precast concrete construction represents a very important percentage of all civil works in the world, given its enormous advantages from a constructive point of view. The reduction of the manufacturing time, the improvement in the quality of the work (due to the improvement of the working conditions), and the reduction of uncertainties related to the geometric and structural deviation of the solution with respect to the project are some of the advantages of this constructive procedure.

Precast concrete is especially efficient in residential structures, which are generally made up of a few groups of different structural elements (columns, slabs, footings, walls, etc.), formed by many identical units. In particular, precast concrete is especially interesting in developing countries, where it can be difficult to find enough skilled labour to perform in situ constructions.

A significant number of these developing countries are in areas of high seismic activity. This is an inconvenience for precast solutions, since it is penalized by international regulations by granting lower reduction coefficients $(\mathrm{R})$ for energy dissipation. This is due to the lower ductility of the connections 
between elements, that is, the limitation is not due to the precast element by itself, but due to the connections between them, which are usually less ductile than traditional solutions cast in situ.

In these cases, the usual way to address the seismic problem is through the use of seismic isolators, dampers, energy dissipators, etc. However, most of them are very expensive solutions, only suitable for special structural elements (tall buildings or very singular buildings). Therefore, they are not economically viable if massive use is intended in areas with low economic resources [1-8].

Therefore, it is necessary to develop low-cost energy dissipation systems that are capable of being implemented in inexpensive precast concrete buildings without involving an unacceptable increase in the total cost of the building [9-11].

Another common problem regarding the structural behavior of a building that had been subjected to an earthquake was that it was useless after the seismic event and, therefore, it had to be demolished. Regarding the situation of collapse during an earthquake, although it is a breakthrough, the economic cost for the community is still very high. Consequently, it is highly desirable that low-cost energy dissipation systems prevent damage to the structure, and therefore it can be re-occupied under safe conditions once the seismic event has passed.

Research in seismic response of structures, especially if they are made of concrete, requires tests that are usually complex and expensive. On the one hand, the performance of scale tests of concrete structural elements is usually not a viable or reliable option. On the other hand, conducting seismic tests usually requires expensive facilities. Therefore, alternative methodologies have been developed which are easier to implement and obtain, although partially, information on the seismic response of the structure $[12,13]$.

First, there are the quasi-static or cyclic tests, also called "pushover", which consist of the application of a low number of low frequency cyclic loads with increasing amplitude until collapse. This type of test characterizes the ductility of the structure, as well as analyzes very specific regions (connections between elements, singular construction details, etc.) [14-21].

Second, there are pseudo-dynamic tests that are a special type of quasi-static test in which displacements are introduced at some points in the structure. The difference is that these displacements are not known before the test and are calculated during the test using a step-by-step integration software. Although it is essentially a static test, it is a very complex technique to implement, mainly because a sophisticated adaptive control equipment is required [22-25].

Third, there are the tests carried out on a shake table, which introduce a true dynamic excitation in the base of the structure. This is the most realistic technique for the seismic testing of structures, since the displacements (and therefore, the accelerations) are applied at the base and the structure is subjected to the inertial forces. However, it is a very complex test because of all the equipment required. In addition, its interpretation is also difficult, since a large number of structural mechanisms are involved in the seismic response. Therefore, this type of tests is usually carried out at the end of a much more extensive testing campaign [26-33].

This paper shows the design and the laboratory validation tests for a new low-cost energy dissipation system that can be applied in precast concrete structures composed of precast footings, precast structural walls and precast concrete slabs. This energy dissipation system basically consists of a specific connection between the precast footing and the precast structural wall, formed by a set of threaded steel bars that connect both elements. During an earthquake, the steel bars undergo plastic deformation, absorbing most of the energy generated by the earthquake and preventing damage to the rest of the building. The additional advantage of this solution is that steel bars are easily replaced after the seismic event.

For the purpose of this paper, a testing campaign was carried out, based on three phases. First, pushover tests were carried out on isolated structural walls formed by a precast structural wall and a precast footing. The aim of this first phase is to define the ductility of the dissipation system, in accordance with the requirements of the American standard ACI 374.2R-13 [34]. 
Secondly, pushover tests were carried out on structural frames, composed of two precast structural walls placed over two precast footings and connected with a precast slab. The aim of this second phase is to evaluate the ductility of the system, including the dissipation capacity of both the connection footing wall and the connection wall slab, in accordance with the aforementioned regulation.

Thirdly, seismic tests using a shake table were carried out on a real-scale three-storey precast concrete building, consisting of two precast structural walls placed over two precast footings, two intermediate precast slabs, and a lightweight roof. In this case, the aim of this third phase is to characterize the dynamic response of the entire structure to a reference earthquake and the energy dissipation capacity of the building.

A customized unidirectional shake table was designed and manufactured specifically for the third test phase. This testing facility was capable of appling a horizontal acceleration up to $1 \cdot \mathrm{g}$ to the structural elements with a height up to $6 \mathrm{~m}$, a weight up to 40 tons, and a frequency up to $8 \mathrm{~Hz}$.

All the precast concrete elements, as well as the low-cost energy dissipation system were invented, developed, and designed by the Spanish company ICONKRETE 2012, S.L., and therefore this company is the owner of this structural solution and the testing results. The precast elements were manufactured by the company ZENET in its factory in Escalonilla (Toledo, Spain). The test was carried out in the Laboratory of Large Structures of the University of Burgos (Burgos, Spain).

The structure of this paper is as follows: In Section 2, the experimental program is presented; in Section 3, the results of the tests are described and discussed; and finally, in Section 4, the conclusions are shown.

\section{Experimental Program}

In this section, the three testing sets of specimens are described, i.e., the isolated structural walls, the structural frames, and the real-scale three-storey precast concrete building, as well as the low-cost energy dissipation system and the shake table. Additionally, the testing procedure is described.

\subsection{Isolated Structural Wall}

As explained before, the isolated structural walls are composed of a precast structural wall and a precast footing, connected through the low-cost energy dissipation system.

The structural wall is a conventional reinforced concrete precast element $3.0 \mathrm{~m}$ high, $2.0 \mathrm{~m}$ wide, and $16 \mathrm{~cm}$ thick. The wall is placed on a reinforced concrete precast footing, $1.1 \mathrm{~m}$ wide, $2.0 \mathrm{~m}$ deep, and $0.6 \mathrm{~m}$ high. In both cases, the concrete quality is C30/37, according to Eurocode 2 [35]. The compressive strength was obtained following the method described in standard EN 12390-3 [36]. The footing includes a longitudinal pocket $36 \mathrm{~cm}$ wide and $36 \mathrm{~cm}$ high, where the structural wall is placed. Underneath the wall, a $2 \mathrm{~cm}$ neoprene band is placed. The structural wall is rigidly connected to the footing through the low-cost energy dissipation system, which is described later (Figure 1).

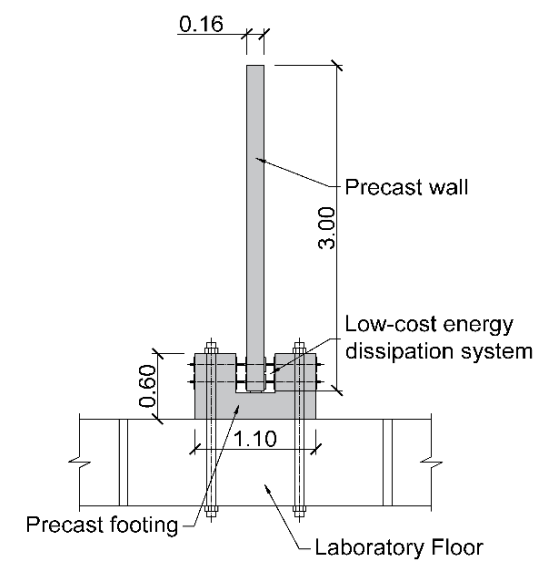

Figure 1. Elevation view of the isolated structural wall. 
The structural wall is reinforced on both faces with steel rebars $8 \mathrm{~mm}$ in diameter spaced $150 \mathrm{~mm}$ in both longitudinal and vertical directions.

\subsection{Structural Frame}

The structural frame is composed of two isolated structural elements, as described above, connected with a structural concrete slab. The inner distance between the walls is $3.84 \mathrm{~m}$. The slab is composed of a self-supporting precast prestressed concrete slab with a thickness of $8 \mathrm{~cm}$ and an upper layer of $14 \mathrm{~cm}$ of cast in situ reinforced concrete. The total thickness of the concrete slab is $22 \mathrm{~cm}$. In all cases, the concrete quality is C30/37, according to Eurocode 2 [35].

A "flexible" connection between the walls and the slab was used, which is described next. The self-supporting precast prestressed concrete slab rests on a steel corner profile anchored to the walls using a set of mechanical anchorages. Additionally, a row of conventional steel rebars sew the joint between the wall and the cast-in situ slab. The rebars are L-shaped with a length of 800 and $200 \mathrm{~mm}$, respectively. The long leg of the rebar is placed horizontally inside the cast-in situ reinforced concrete slab, while the short leg is placed vertically inside the wall. The diameter of the rebars are $20 \mathrm{~mm}$, with a spacing of $50 \mathrm{~cm}$. From the structural point of view, this connection is very effective under vertical loads, such as self-weight, dead loads, and vertical live loads. Under horizontal loads, similar to the ones caused by the earthquake, this connection is able to withstand negative bending moments, but not positive bending moments, resulting in a semi-rigid joint. (Figure 2).

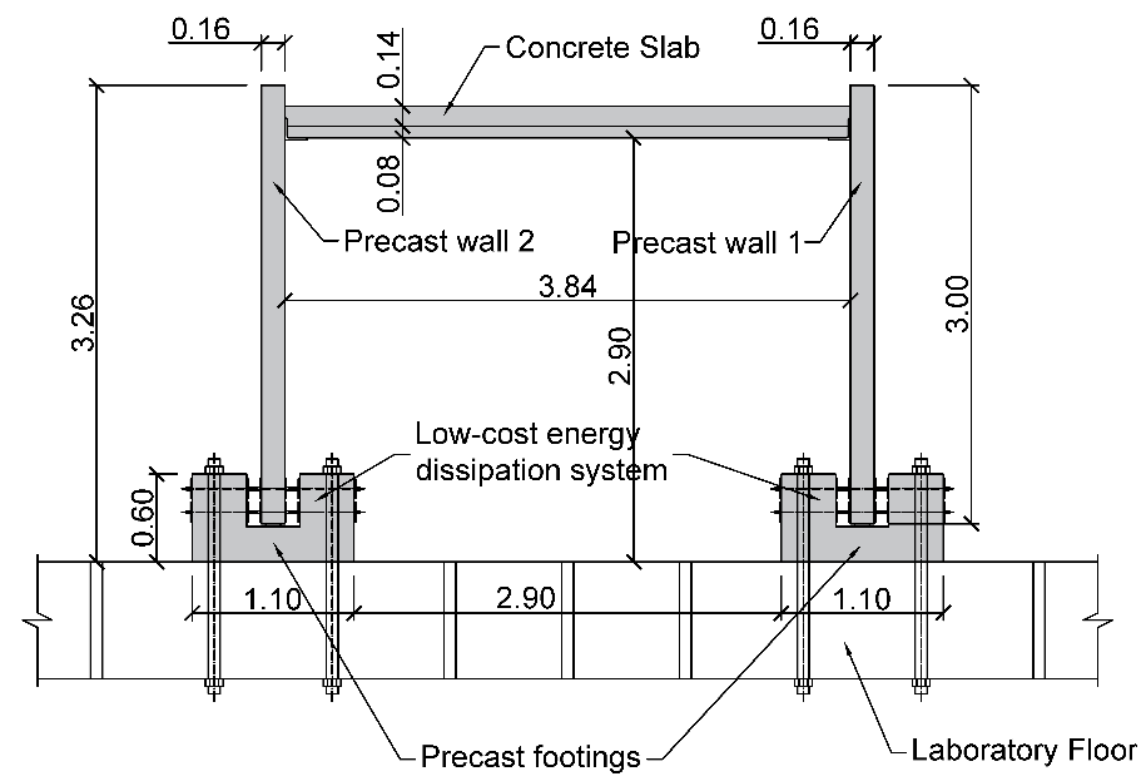

Figure 2. Elevation view of the structural frame.

\subsection{Real-Scale Three-Storey Precast Concrete Building}

Finally, the real-scale three-storey precast concrete building is composed of two precast concrete walls, two precast footings, two concrete slabs, and a flexible steel roof. The inner distance between the two walls is $2.25 \mathrm{~m}$. In all cases, the concrete quality is C30/37, according to Eurocode 2 [35].

The structural walls are conventional reinforced concrete precast elements $5.62 \mathrm{~m}$ high, $2.0 \mathrm{~m}$ wide, and $16 \mathrm{~cm}$ thick. They are placed on the same reinforced concrete precast footings as described above.

Each of the two concrete slabs is composed of a self-supporting precast prestressed concrete slab with a thickness of $8 \mathrm{~cm}$ and an upper layer of $14 \mathrm{~cm}$ of cast-in situ reinforced concrete. The connection between the slab and the wall is the same as the one described in the previous subsection. The slabs are located at $2.45 \mathrm{~m}$ and $4.20 \mathrm{~m}$ high. Finally, the roof is located at the top of the walls. It is a lightweight roof formed by an aluminium sheet which is bolted to two I-beams. (Figure 3). 


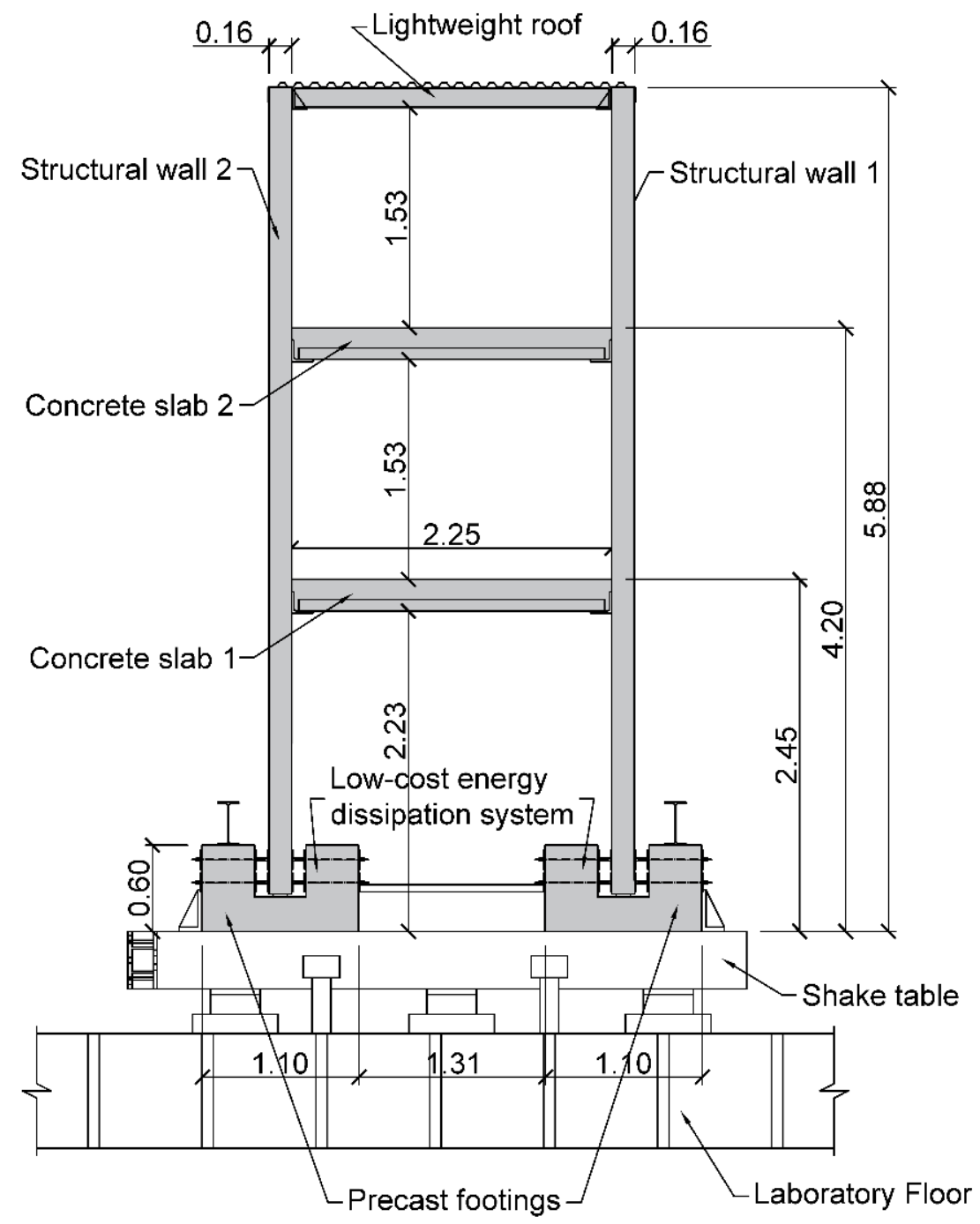

Figure 3. Elevation view of the real-scale three-storey precast concrete building, including the shake table.

\subsection{Low-Cost Energy Dissipation System}

The low-cost energy dissipation system is a device placed on the connection between the footing and the wall. As previously explained, the footing includes a longitudinal pocket $36 \mathrm{~cm}$ wide and $36 \mathrm{~cm}$ high, where the structural wall is placed. It consists of a set of threaded bars placed orthogonally to the wall, in such a way that they cross both the footing and the wall. In this case, the system consists of a total of 10 threaded bars, $20 \mathrm{~mm}$ diameter, and placed in two rows, spaced $300 \mathrm{~mm}$ in both longitudinal and vertical directions. The property class of the steel for the threaded bars is 3.6, according to ISO 898-1 [37].

Since the wall has a thickness of $16 \mathrm{~cm}$, there are two $10 \mathrm{~cm}$ gaps between the wall and the footing, one at each side of the wall (Figure 4). Additionally, nuts located at both sides of the wall and the footing are required to fix the wall in its proper position.

When an earthquake occurs, it is expected that most of the energy is consumed in the plastic deformation of the bars, preventing the rest of the structure from damage. The number, position, distribution, and diameter of the bars, as well as the steel quality must be specifically designed to each particular structure, depending on the dimensions of the structure and the location of the building.

One additional advantage of this solution is that bars are easily replaceable once an earthquake has occurred. 


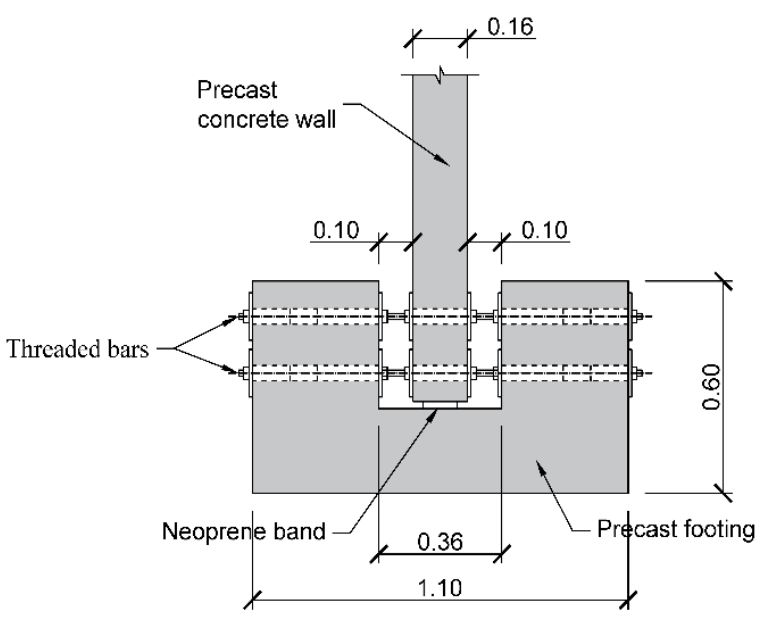

Figure 4. Scheme of the low-cost energy dissipation system.

\subsection{Shake Table}

A unidirectional shake table was specifically designed and manufactured for this research, in order to fulfill the testing requirements of the real-scale three-storey precast concrete building.

The shake table is composed of a cast steel slab $4.14 \mathrm{~m}$ long, $2.87 \mathrm{~m}$ wide, and $0.65 \mathrm{~m}$ high. It rests on six circular elastomeric bearing pads, reinforced with steel plates. The dimensions of the bearings are $350 \mathrm{~mm}$ diameter and $137 \mathrm{~mm}$ high.

The seismic loads are applied using a tension-compression MTS 201.70F dynamic actuator (MTS, Eden Prairie, MN, USA), with a capacity of $\pm 1000 \mathrm{kN}$. The actuator has a load cell MTS 661.31F-01 (MTS, Eden Prairie, MN, USA), with a range of $\pm 1000 \mathrm{kN}$ and an error of below $1 \%$ of the range. During the testing, the actuator provided a longitudinal displacement. In order to prevent undesirable transversal movements, four stoppers were placed in both lateral sides of the steel slab (Figures 5 and 6).

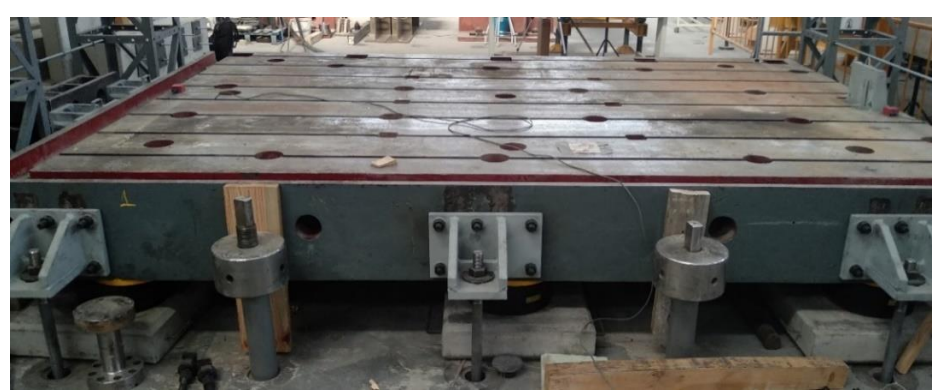

Figure 5. Shake table.

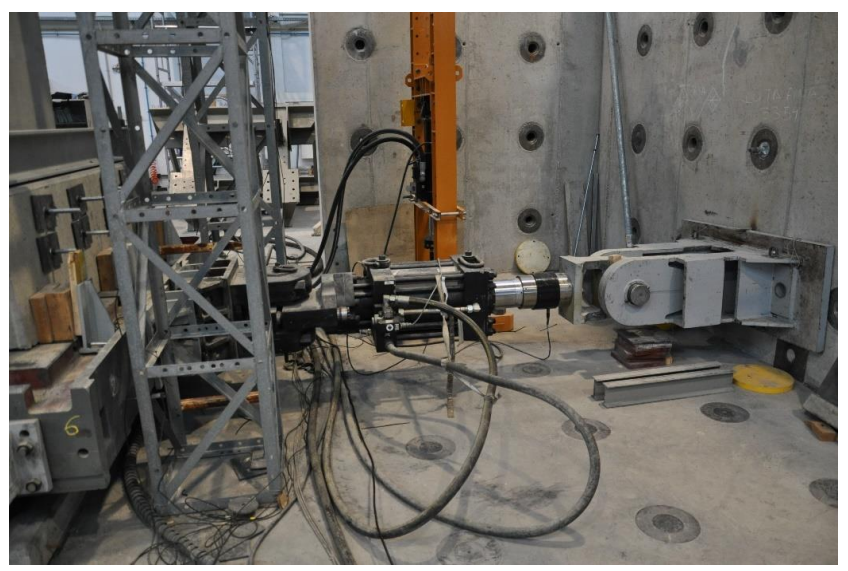

Figure 6. Detailed view of the dynamic actuator. 


\subsection{Testing Procedure}

\subsubsection{Pushover Tests on Isolated Structural Walls and Structural Frames}

The pushover tests carried out on the isolated structural walls and the structural frames were developed according to the American standard ACI374.2R-13 [34]. According to this standard, four levels of structural performance under seismic events are defined, which are "operational", "immediate occupancy", "life safety", and "collapse prevention", moving from least to greatest lateral drift ratio (Figure 7).

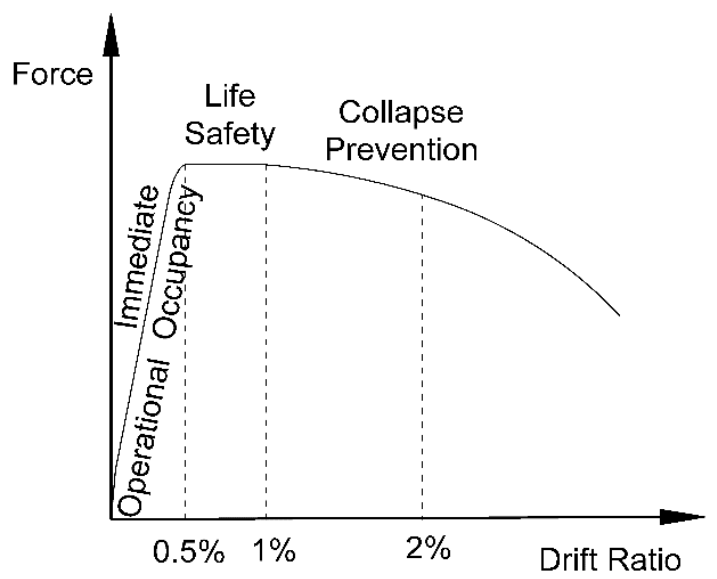

Figure 7. The four levels of structural performance, according to ACI 374.2R-13 [34].

According to the goal of this research, the "immediate occupancy" level is considered for design purposes, which implies that the building can be used once the seismic event has passed. At this level, the stiffness requirements are high, the behavior of the structure must be within the elastic-linear range and, consequently, the seismic loads developed are important. The standard used does not consider other criteria apart from those concerning structural damage. That is the reason why non-structural issues, such as furniture overturning or partition damage, have not been considered in this research. However, it is worth noting that the "immediate occupancy" level implies a very low risk of life-threatening injury as a result of structural damage.

The lateral drift ratio is defined as the quotient between the horizontal displacement of the structure at the loading point and the distance from this point to the centroid of the connection between the wall and the footing. In this case, the maximum allowable lateral drift ratio (see Figure 7 ) is $0.5 \%$. Additionally, some other criteria must be fulfilled [34]:

1. No plastic behavior is observed in the structure, neither concrete nor steel rebars;

2. Crack width should be below $1.6 \mathrm{~mm}$;

3. No concrete crushing is observed.

Regarding the testing procedure, it consisted of applying a quasi-static horizontal load near the top of the structural element (wall or frame). Displacement controlled reverse cyclic tests were performed. The number of loading cycles for each amplitude of the imposed displacement was kept at two. The value of the amplitude depends on the critical drift $\varphi_{y}$, which is defined as the drift associated with yielding. The first couple of cycles corresponded to a drift equal to $0.5 \cdot \varphi_{\mathrm{y}}$, the second couple of cycles, to a drift equal to $\varphi_{\mathrm{y}}$, the third one, to a drift equal to $2 \cdot \varphi_{\mathrm{y}}$, and for the remaing couple of cycles the amplitude increased in $1 \cdot \varphi_{\mathrm{y}}$, i.e., $3 \cdot \varphi_{\mathrm{y}}, 4 \cdot \varphi_{\mathrm{y}}, 5 \cdot \varphi_{\mathrm{y}}$, and so on to the conclusion of the test. The test concluded when the maximum load of one cycle was more than $20 \%$ lower than the total maximum load of all cycles, according to ACI 374.2R-13 [34].

In the case of the tests on the isolated structural walls, the load was applied at a height of $2.5 \mathrm{~m}$ and the critical drift $\varphi_{\mathrm{y}}$ corresponded to a horizontal displacement of $10.6 \mathrm{~mm}$ at the load application 
point. In the case of the tests on the structural frames, the load was applied at a height of $2.94 \mathrm{~m}$ and the critical drift $\varphi_{\mathrm{y}}$ corresponded to a horizontal displacement of $12.6 \mathrm{~mm}$ at the load application point.

The tests on both the isolated structural walls and the structural frames were carried out using a tension-compression MTS 201.70F dynamic actuator (MTS, Eden Prairie, MN, USA), with a capacity of $\pm 1000 \mathrm{kN}$. The actuator had a load cell MTS 661.31F-01 (MTS, Eden Prairie, MN, USA), with a range of $\pm 1000 \mathrm{kN}$ and an error of below $1 \%$ of the range. The tests were displacement controlled. This testing procedure provided greater safety against unexpected collapse and it better meet the requirement of the ACI 374.2R-13 [34].

In order to analyze the structural behavior of the testing specimens, a number of sensors were used, including inclinometers (model PST300, Pewatron AG, Zurich, Switzerland), linear potentiometer displacement transducers (ranged from 50 to $500 \mathrm{~mm}$, Novotechnik, Ostfildern, Germany), and uniaxial strain gauges (150 mm length, Tokyo Sokki Kenkyujo Co., Ltd., Tokyo, Japan). Figures 8 and 9 show the position of the sensors in each of the two sets of testing specimens, i.e., the isolated structural walls and the structural frames.

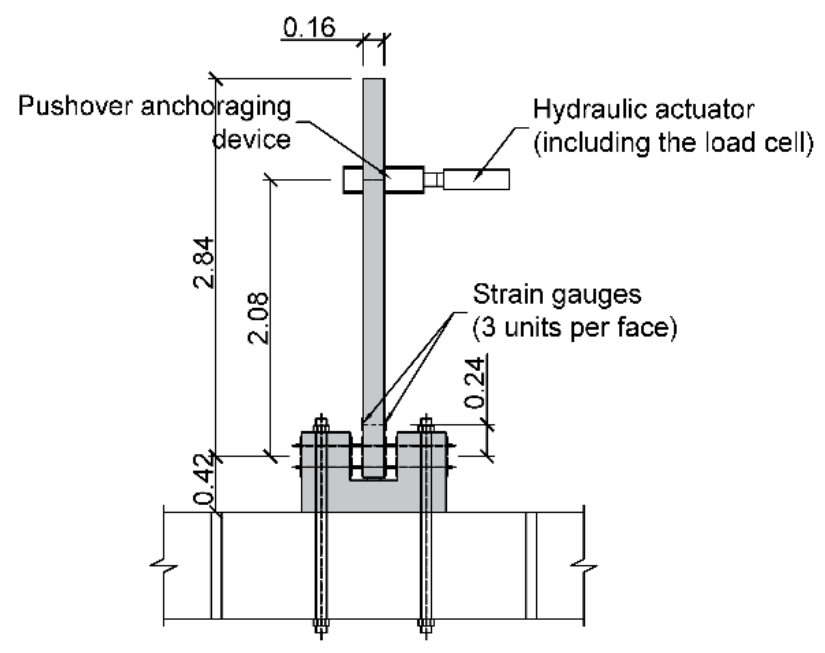

(a)

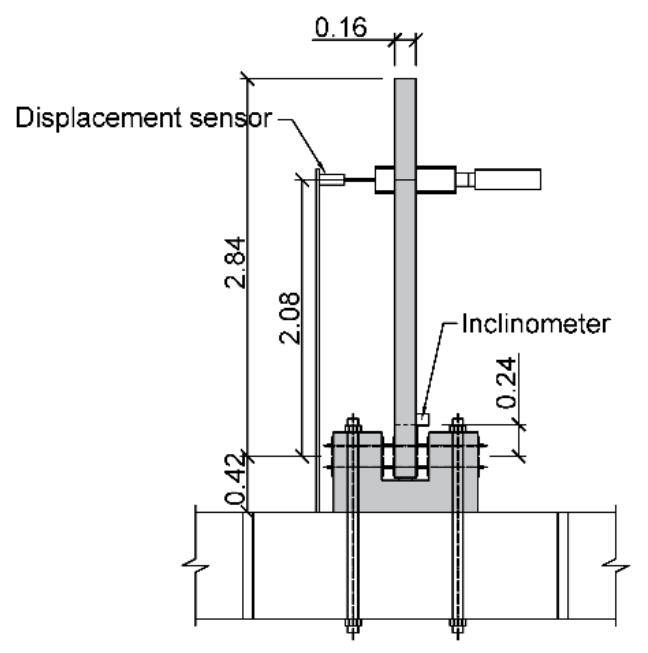

(b)

Figure 8. (a and $\mathbf{b})$ Location of the sensors in the isolated structural walls.
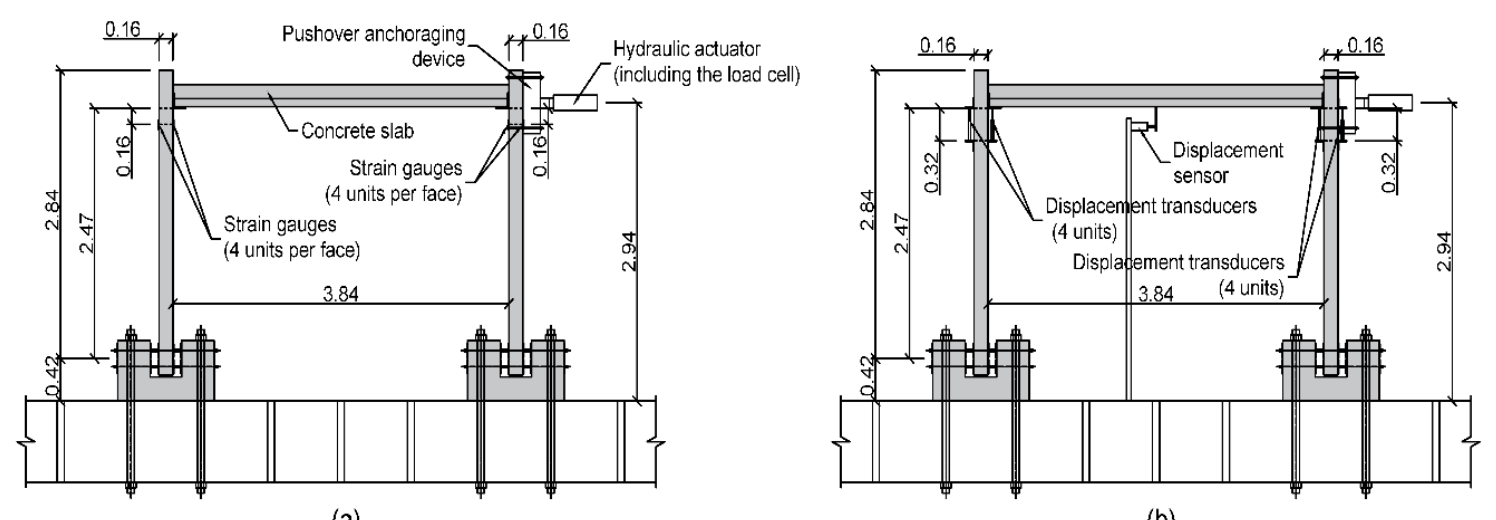

(b)

Figure 9. (a and $\mathbf{b}$ ) Location of the sensors in the structural frames.

\subsubsection{Seismic Tests on Real-Scale Three-Storey Precast Concrete Building}

The third phase consists of seismic tests on a real-scale three-storey precast concrete building. In this case, a representative earthquake was reproduced in the laboratory, namely "El Centro" (an earthquake that occurred in the city of El Centro, California, USA in 1979). More specifically, the accelerogram belonging to an orientation of $220^{\circ}$ was considered, because this was the most 
unfavourable in terms on maximum horizontal accelerations. The accelerogram was obtained from the USGS (United States Geological Survey, USA) (Figure 10a).

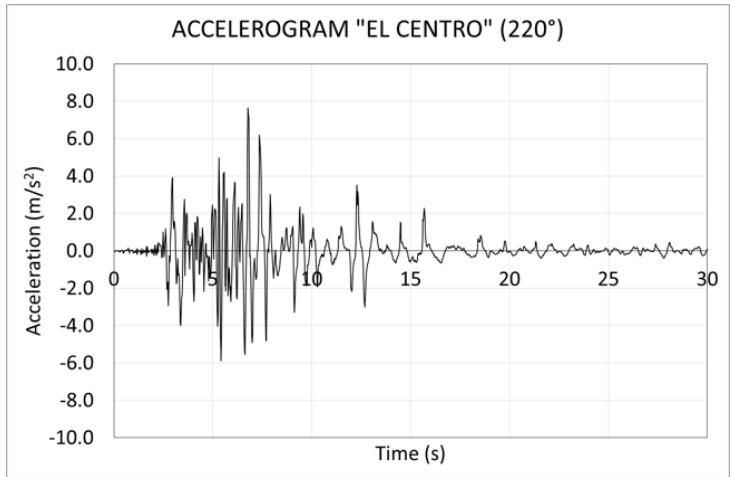

(a)

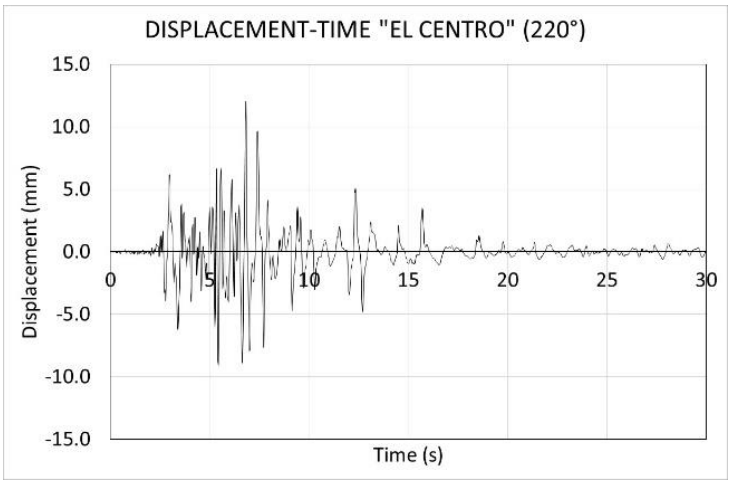

(b)

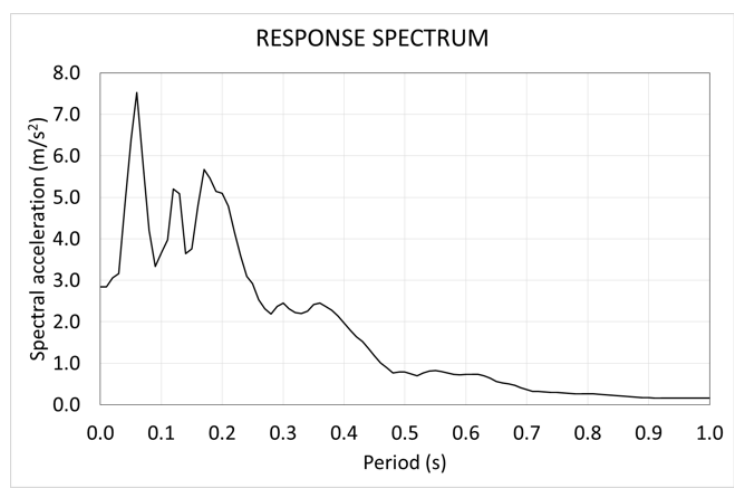

(c)

Figure 10. Earthquake "El Centro". (a) Accelerogram; (b) diagram of horizontal displacement vs. time; (c) response spectrum.

The accelerogram is first transformed in a diagram of horizontal displacement verus time, which is the input signal introduced to the dynamic actuator control equipment (Figure 10b). Additionally, the response spectrum of the earthquake is shown (Figure 10c).

Figure 10c reveals that this earthquake causes the highest acceleration for structures with a natural period of $0.06 \mathrm{~s}$, i.e., for structures with a natural frequency of $16.7 \mathrm{~Hz}$. However, this earthquake is not only very dangerous for rigid structures, but it also provides acceleration values greater than the ground acceleration up to a period of $0.25 \mathrm{~s}$, i.e., a frequency of $4 \mathrm{~Hz}$.

The earthquake was not applied directly on the building, but in a progressive way, similar to foreshocks before the main earthquake. A total of six foreshocks were applied to the building before the main earthquake. To perform it, the ordinate of the seismic signal (i.e., the diagram of horizontal displacement vs. time) was multiplied by a factor. For the first foreshock, the factor was 0.05, i.e., the shape of this earthquake is homothetic to the real "El Centro" earthquake but the displacements are only $5 \%$ of the main earthquake. For the rest of the foreshocks, the factors were $0.1,0.3,0.5,0.7$, and 0.9 respectively. Finally, the main earthquake was applied.

The sensors used to monitor this test were load cell, accelerometers on the shake table, the intermediate slabs at the top of the walls, and displacement transducers in several positions (Figure 11). 


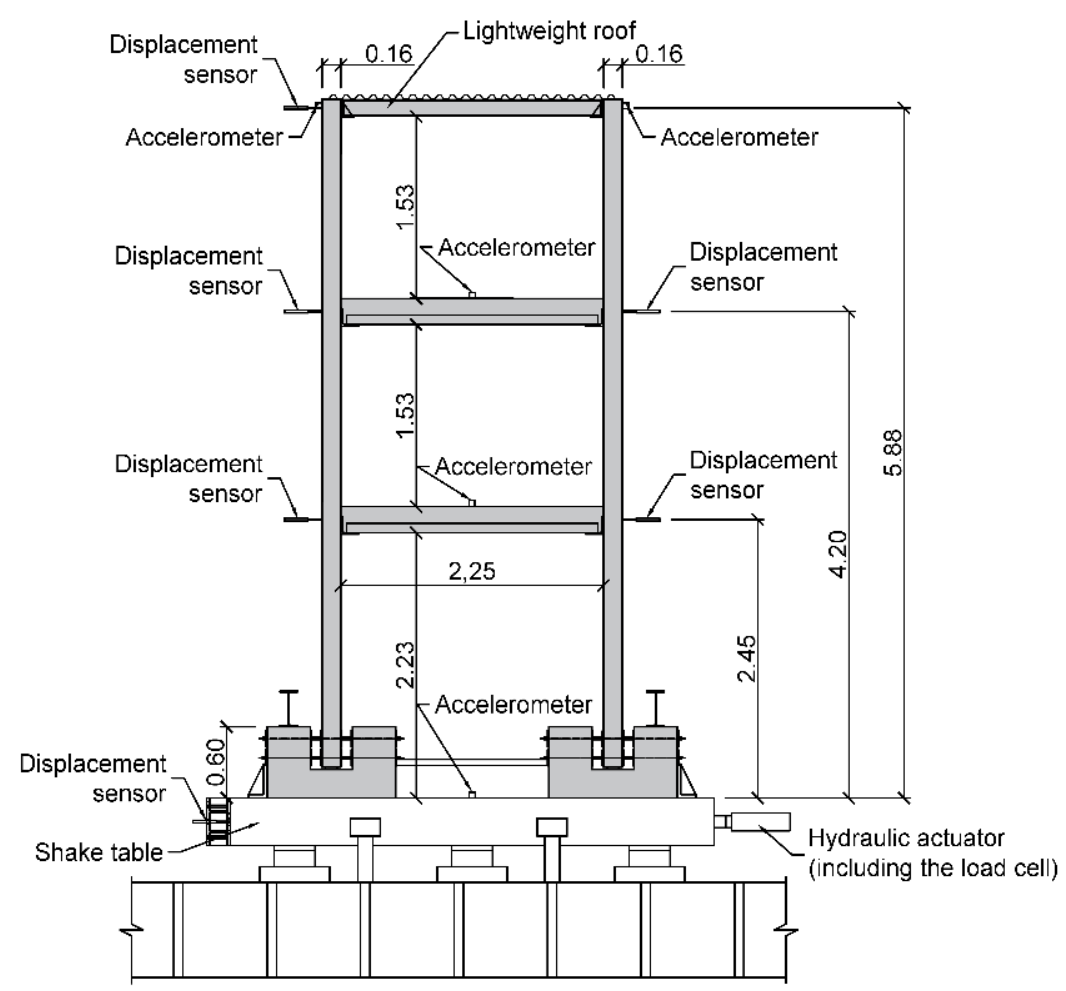

Figure 11. Location of the sensors in the building.

Figure 12 shows a general view of the testing. As can be observer, in addition to the self-weight of the building, a dead load of $1.50 \mathrm{kN} / \mathrm{m}^{2}$ was included on the intermediate slab. This load was materialized using water tanks.

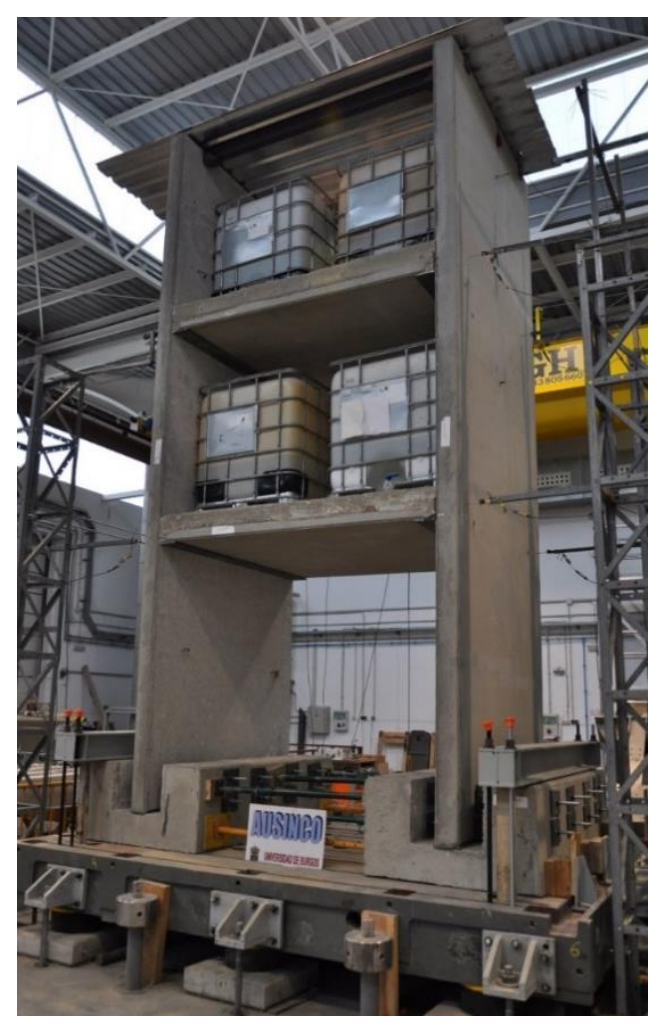

Figure 12. General view of the real-scale three-storey precast concrete building. 
Additionally, a one-cycle impulsive test was performed, before and after the seismic tests, in order to measure the natural frequency and the damping ratio of the building and to compare them with the excitation frequency of the earthquake. Moreover, the comparison of the natural frequency and damping ratio values, before and after the seismic event (including the main earthquakes and the foreshocks), provide useful information about the damage caused by the seismic tests.

In this case, a displacement-time one-cycle square wave signal was applied, with an excitation frequency of $5 \mathrm{~Hz}$ and an amplitude of $1 \mathrm{~mm}$.

\section{Experimental Results and Discussion}

Next, the experimental results of the testings are exposed. In this case, the results of the most representative test of each phase are shown.

\subsection{Pushover Tests on Isolated Structural Wall}

As previously explained, the aim of this testing phase is to evaluate the ductility of the low-cost energy dissipation system by considering diagrams of horizontal load versus drift, drift versus strain in concrete, and bending moment versus rotation.

\subsubsection{Diagram of Horizontal Load versus Drift}

Figure 13 shows the diagram of horizontal load versus lateral drift (hysteresis loops). In this case, positive values mean push, and negative values mean pull.

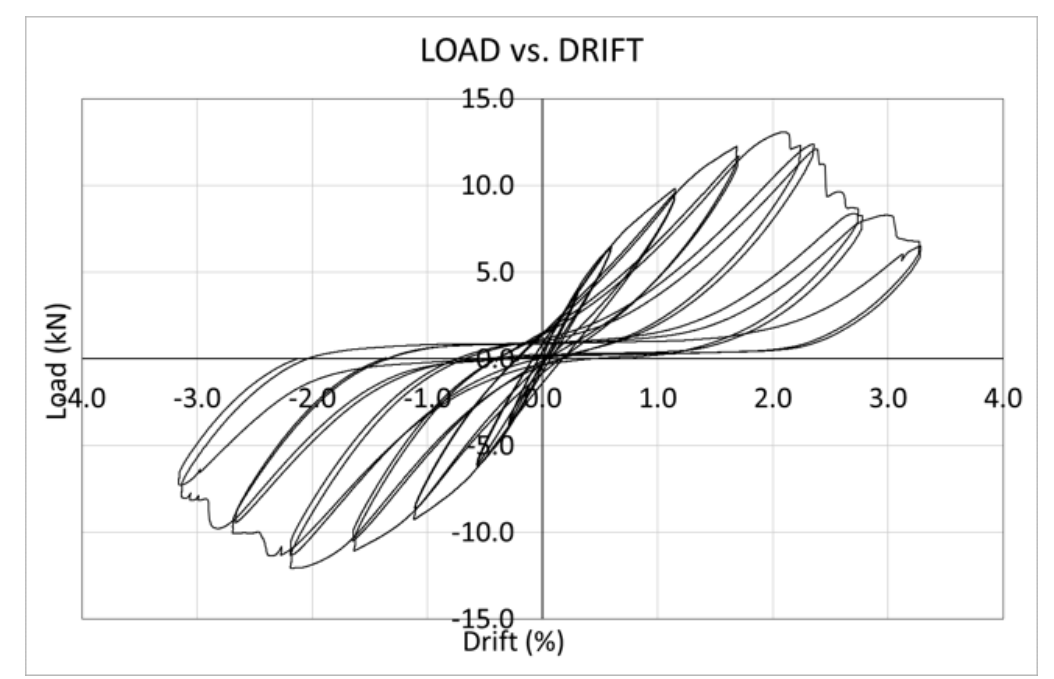

Figure 13. Diagram of load vs. drift. Pushover test on isolated structural wall.

Some interesting conclusions can be obtained from Figure 13. First, a symmetric behavior under push and pull is obsesrved, as expected. Second, it can be observed that the behavior of the specimen is linear elastic up to the critical drift $\varphi_{\mathrm{y}}$ (which is $0.5 \%$ according to ACI374.2R-13 [34]). In consequence, this solution agrees with one of the requirements of the American standard mentioned above.

Once the drift is greater than $0.5 \%$, a progressive plastic behavior is observed, i.e., the specimen begins to dissipate energy at the expense of a higher deformation. The area enclosed by the hysteresis loop is proportional to the energy dissipated during the testing and represents the structural element capacity to mitigate the earthquake effect inelastically.

The maximum loads obtained during the testing were $13.0 \mathrm{kN}$ in the push phase and $12.0 \mathrm{kN}$ in the pull phase. In both cases, these loads correspond to a drift of $2 \%$, which is four times greater than the critical drift. The loads obtained at the critical drift were $6.5 \mathrm{kN}$ in the push phase and $6.2 \mathrm{kN}$ in the pull phase. 


\subsubsection{Diagrams of Drift versus Strain in Concrete}

Figure 14 shows the relationship between the drift of the wall and the average vertical strain of the concrete at the base of the wall, at both the dorsal face (where the actuator is placed) and the frontal face (the opposite side). In this case, a positive value of strain denotes tension, and a negative value denotes compression.

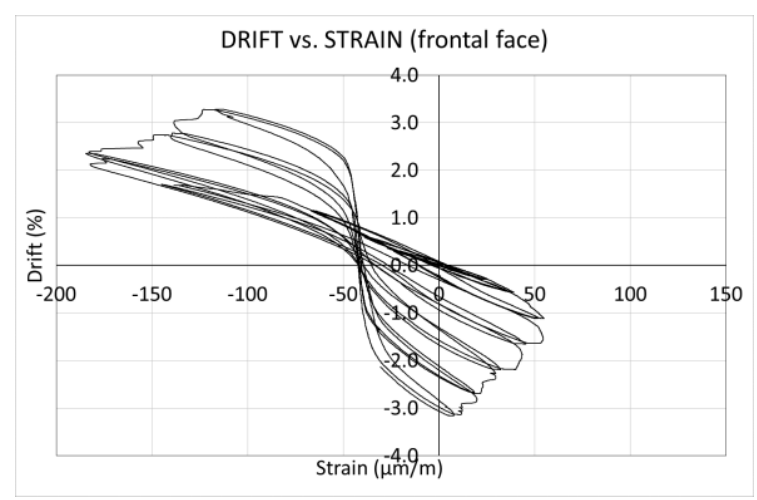

(a)

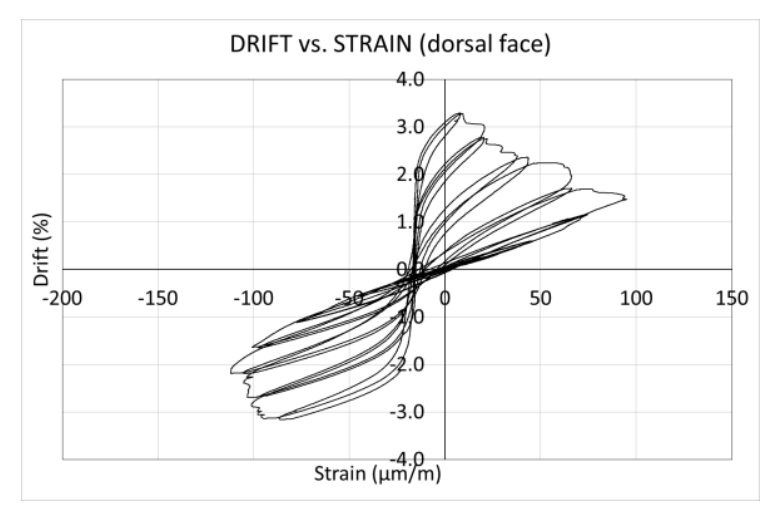

(b)

Figure 14. Diagrams of drift vs. vertical strain. Pushover test on isolated structural wall. (a) Drift versus strain in the frontal face; (b) drift versus strain in the dorsal face.

Figure 14 shows a linear elastic behavior of concrete through the test, since the maximum measured strain is around $200 \mu \mathrm{m} / \mathrm{m}$ under compression and $90 \mu \mathrm{m} / \mathrm{m}$ under tension, which is smaller than maximum elastic strain of concrete (which can be estimated around $1000 \mu \mathrm{m} / \mathrm{m}$ under compression and $100 \mu \mathrm{m} / \mathrm{m}$ under tension). This is particularly true for the critical drift $\varphi_{\mathrm{y}}$, where the maximum measured strain is significantly smaller (around $50 \mu \mathrm{m} / \mathrm{m}$ under compression and $10 \mu \mathrm{m} / \mathrm{m}$ under tension). The results satisfy the ACI374.2R-13 [34].

The measured vertical strain values are in accordance with the visual inspections carried out at the end of the tests, where no visible cracks in concrete wall were observed, and, of course, no concrete crushing occured.

The diagrams in Figure 14 show an asymmetric behavior, i.e., compression strains are greater than tension strain. This could be because under tension, small microcracks in concrete occur, relaxing tension stress in concrete (and as a counterpart increasing the tension stress of the reinforcement), resulting in smaller values of tension strain.

This result confirms that the plastic behavior shown by the isolated structural wall is completely caused by the low-cost energy dissipation device. Moreover, once the plastic behavior of the structural wall is observed, a progressive decrease of the maximum vertical strain of concrete occurs. This is because the elastic energy stored in the wall progressively flows to the energy dissipation device, preventing the wall from structural damage.

\subsubsection{Diagram of Bending Moment versus Rotation}

Figure 15 shows the diagram of bending moment versus rotation of the connection between the wall and the footing. The bending moment is defined as the product of the horizontal force and the vertical distance between the force and the centroid of the low-cost energy dissipation system. The rotation is measured using an inclinometer placed at the level of the centroid of the energy dissipation device (see Figure 8). Positive values mean push, and negative values mean pull.

Figure 15 confirms the findings shown in previous figures. On one side, it is observed that up to the critical drift $\varphi_{\mathrm{y}}$, the connection shows a linear elastic behavior. The slopes of the curves are high and quite similar under loading and unloading. The area under the hysteresis loop is small, which means that there is no energy dissipation. Additionally, no lose of stiffness is observed. 
Once the structure reaches a drift of $2 \%$, a plastic behavior starts to occur. Then, a progressive decrease of the stiffness of the connection is observed. The area under the hysteresis loop gradually increases, which reveals that there is a progressive energy dissipation. In general, a symmetric behavior of the connection is observed.

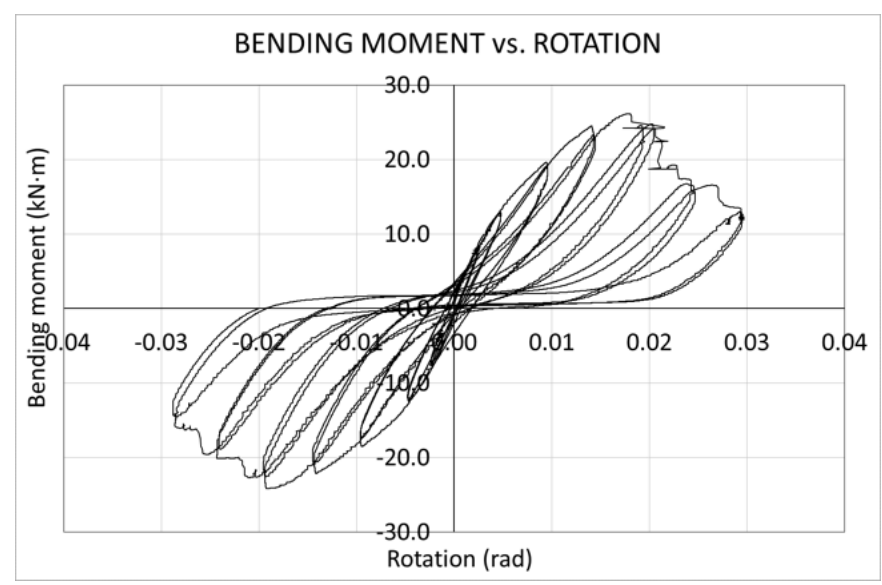

Figure 15. Diagram of bending moment vs. rotation. Pushover test on isolated structural wall.

\subsection{Pushover Tests on Structural Frames}

As previously explained, the aim of this testing phase is to evaluate the ductility of the frame, including the low-cost energy dissipation system, as well as the "flexible" connection between the slab and the wall. To obtain it, the diagrams of load versus drift, drift versus strain in concrete, and bending moment versus rotation are shown.

The tests carried out on the structural frames are not reversal (i.e., push and pull), but they are push and "unpush" (i.e., push the frame up to the maximum displacement of each cycle and return it back to the displacement until zero).

\subsubsection{Diagram of Horizontal Force versus Drift}

Figure 16 shows the diagram of horizontal load versus lateral drift (hysteresis loops).

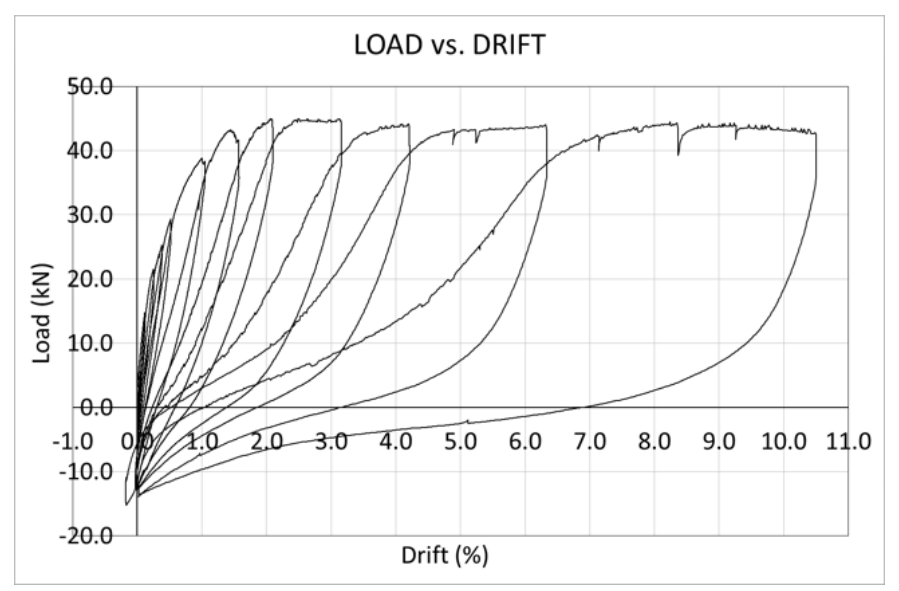

Figure 16. Diagram of load vs drift. Pushover test on structural frame.

Some interesting findings can be observed from Figure 16. First, it is highlighted that a linear-elastic behavior is observed until the critical drift $\varphi_{\mathrm{y}}$. This result agrees with the American standard ACI374.2R-13 [34]. Once the critical drift is reached, a progressive plastification of the structure 
occurs. The area under the hysteresis loop progressively increases, which denotes that an energy dissipation process occurs.

The maximum load is reached for a drift of $3 \%$, i.e., six times the critical draft. Beyond this value, the load does not increase or decrease, but it remains almost constant. However, the area under the hysteresis loops significantly increases. The structural solution shows a huge capacity of energy dissipation without losing structural capacity.

\subsubsection{Diagrams of Drift versus Strain in Concrete}

Figure 17 shows the relationship between the drift of the walls and the average vertical strain of the walls' concrete, near but below the connection with the slab, at both the internal and the external faces. In this case, a positive value of strain denotes tension, and a negative value denotes compression.

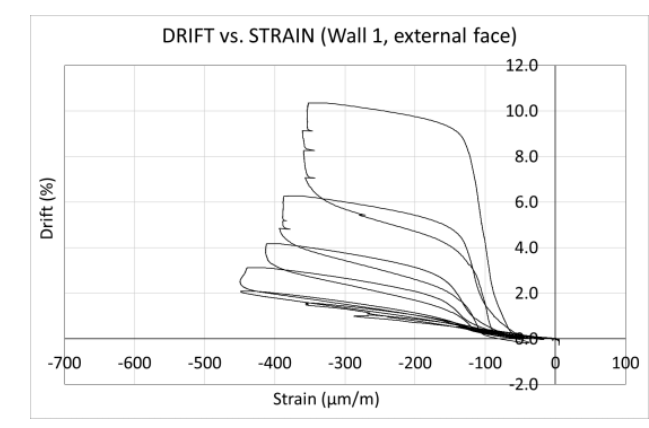

(a)

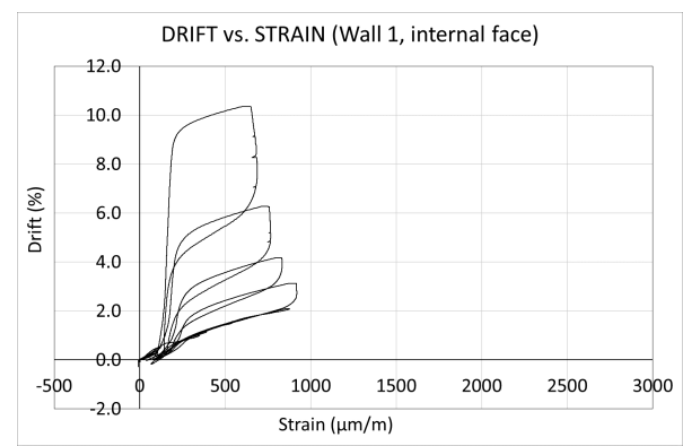

(c)

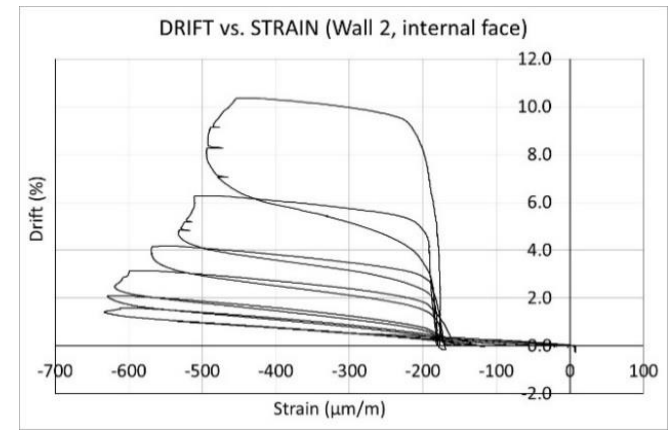

(b)

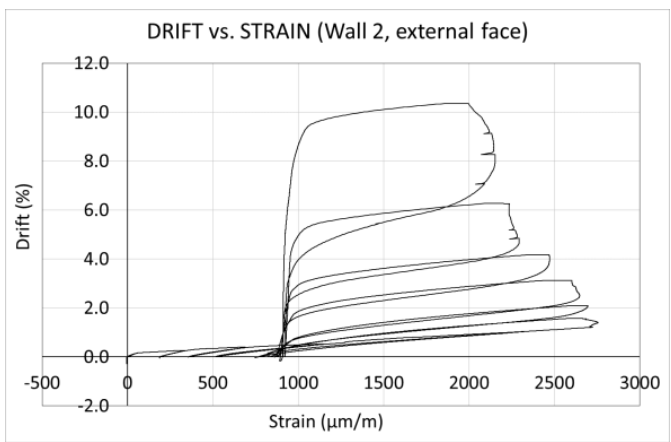

(d)

Figure 17. Diagrams of drift vs. vertical strain. Pushover test on structural frame. (a) Drift versus strain in the external face of wall 1; (b) drift versus strain in the internal face of wall 2; (c) drift versus strain in the internal face of wall $1 ;(\mathbf{d})$ drift versus strain in the external face of wall 2.

Figure 17 reveals the behavior of the connection between the slab and the wall. First, a linear-elastic behavior of the connection, up to a drift of $2 \%$, is observed. In Wall 1 , the one in contact with the actuator, compression strain is observed in the exterior face, as well as tension strain in the interior face. On the contrary, in Wall 2, tension strain is observed in the exterior face, as well as compression strain in the interior face. In each loading cycle, the loading and the unloading branches are almost identical and the area under the hysteresis loop is small, which denotes an absence of energy dissipation. During this first phase of the testing, the visual inspections revealed very small horizontal cracks in the walls (especially in the external face of Wall 2 where the tension strain was larger) with a crack width below $0.2 \mathrm{~mm}$, i.e., clearly smaller than $1.6 \mathrm{~mm}$ which is the maximum allowable crack width defined by the ACI374.2R-13 [34]. No concrete crushing occurred.

The maximum measured strain values belong a drift of $2 \%$. Beyond this value, there was a progressive decrease in the maximum measured strain, which denotes that the stiffness of the connection between the slab and the wall decreased and a plastic hinge appeared in this connection. Moreover, 
this plastic hinge showed an asymmetric behavior, i.e., its structural behavior was different when it was subjected to a positive bending (tension in the inner face of the wall and the lower face of the slab) or a negative bending (tension in the outer face of the wall and the upper face of the slab).

Because of the type of loading cycles of the test, the connection between Wall 1 and the slab was always under positive bending while the connection between Wall 2 and the slab was always under negative bending. Wall 1 showed values of strain (both tension and compression) lower than the values observed in Wall 2. This means that the connection shows a stiffness under positive bending smaller than the one under negative bending.

Once the drift was beyond $2 \%$, a clear plastic behavior started to be observed. In each loading cycle, the loading and the unloading branches were different and the area under the hysteresis loop increased with the cycles, which denoted an increased ability of the connection to dissipate energy. In this case, the visual inspections carried out during the testings revealed small horizontal cracks in the walls (especially in the external face of Wall 2 where the tension strain was larger). However, the crack widths were always below $1.6 \mathrm{~mm}$ which is the maximum allowable crack width defined by the ACI374.2R-13 [34]. No concrete crushing occurred.

\subsubsection{Diagram of Bending Moment versus Rotation}

Figure 18 shows the diagrams of bending moment versus rotation of the connections between Walls 1 and 2 and the slab. The bending moment is defined as the product of the horizontal force and the vertical distance between the force and the centroid of the low-cost energy dissipation system. This is, in fact, a "global bending moment" of the frame, and not the real moment of the connection between the wall and the slab. The rotation is defined as the variation of the inner angle between the wall and the slab.

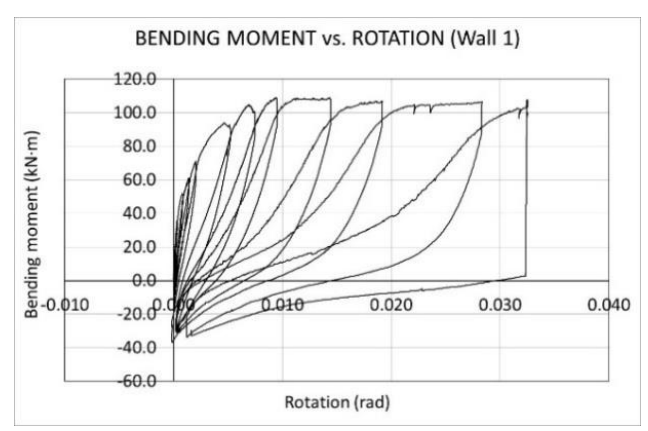

(a)

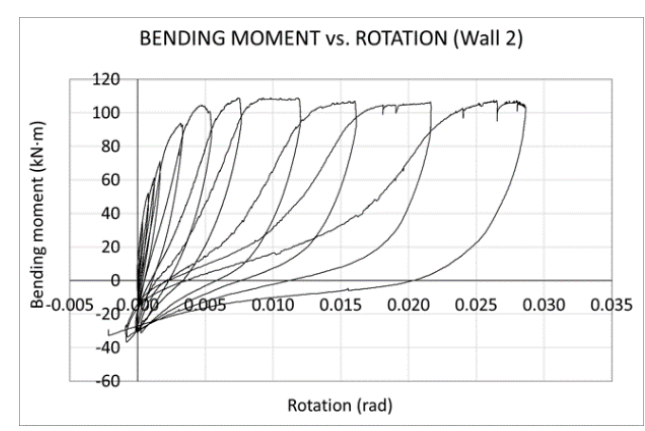

(b)

Figure 18. Diagrams of bending moment vs. rotation. Pushover test on structural frame. (a) Bending moment versus rotation of the connection between wall 1 and slab; (b) bending moment versus rotation of the connection between wall 2 and slab.

The behavior observed in Figure 18 agrees with the one shown in Figure 16. The first hysteresis cycles (up to a drift of $2 \%$ ) reveal a linear-elastic behavior of the connections. The loading and the unloading branches are very similar, and the areas enclosed by the hysteresis loop are very small.

Beyond a drift of $2 \%$, the structure begins to show a plastic behavior. In each hysteresis loop, the slope of the curve bending moment versus rotation progressively decreases, and the area enclosed by the hysteresis loop progressively increases. Consequently, the energy dissipation capacity of the connection between the wall and the slab increases. Additionally, the permanent rotation corresponding to null bending moment increases in each cycle, which denotes that the connection suffers damage in each cycle.

An unexpected behavior is observed during the last cycle in the diagram concerning Wall 1. In particular, there is an interruption of the data capture from rotations around $0.03 \mathrm{rad}$. This can be 
explained because the measurement range of the transducers used to calculate rotations was exceeded. As a result, the transducers are detached from the concrete surfaces and there is no data collection.

When both connections are compared, it is observed that the one placed in Wall 1 (and consequently subjected to positive bending) shows less stiffness than the one in Wall 2 (subjected to negative bending). This finding agrees with the results of Figure 17. Moreover, the permanent rotation corresponding to null bending moment in the connection of Wall 1 is larger than the one in Wall 2.

\subsection{Seismic Tests on Real-Scale Three-Storey Precast Concrete Building}

Once the two testing phases have been completed (the first one on isolated structural walls and the second one on structural frames), the seismic tests on a real-scale three-storey precast concrete building were performed. The aim of this third testing phase is to validate the structural solution implemented on a real building subjected to an earthquake. In this case, the structural behavior of the building under the seismic events mainly depends on the connections, both the low-cost energy dissipation systems placed on the connections between the walls and the footings and the flexible connections between the walls and the slabs.

To obtain it, the following parameters are monitored during a real seismic event: Longitudinal displacement of the shake table, longitudinal displacements of the building at the storey levels, and longitudinal accelerations of the shake table and the building. The results shown in the following figures belongs only to the main earthquake and not to the foreshocks.

\subsubsection{Longitudinal Displacement of the Shake Table and the Building}

Figure 19 shows the diagrams of the longitudinal displacement versus time during the "El Centro" earthquake at the following locations: shake table, Concrete Slab 1, Concrete Slab 2 and lightweight roof.

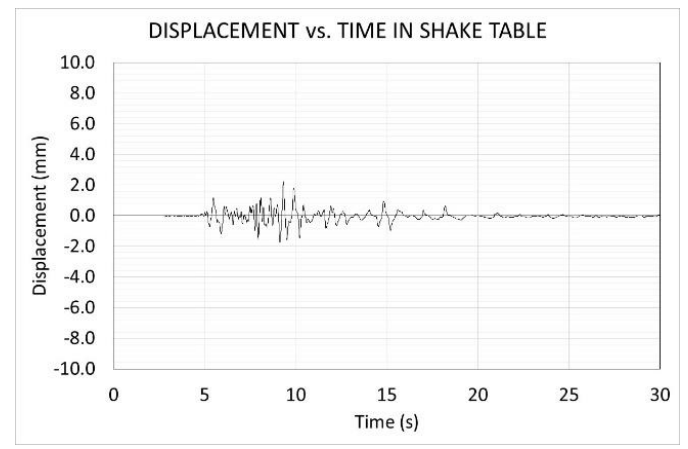

(a)

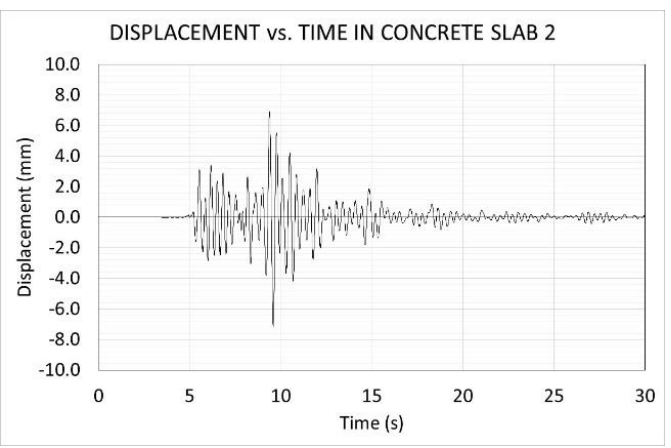

(c)

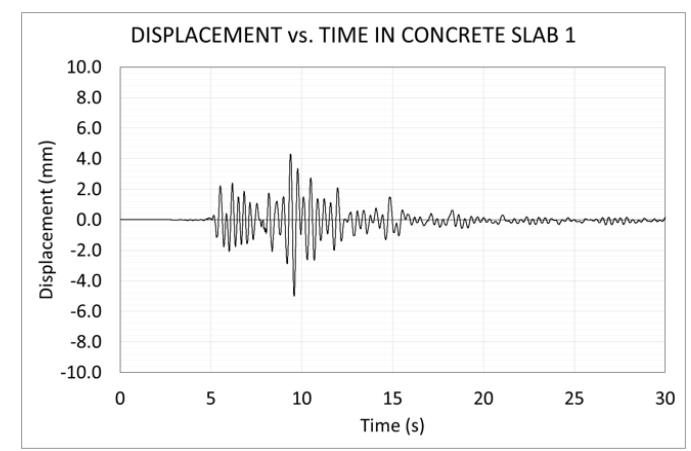

(b)

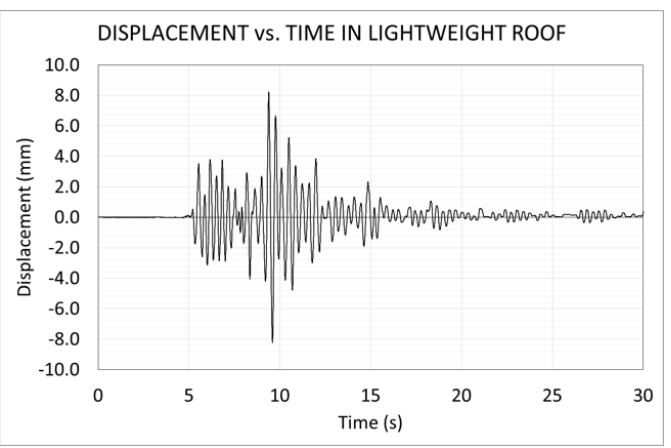

(d)

Figure 19. Diagrams of longitudinal displacement vs. time at different locations, from shake table to lightweight roof. (a) Displacement versus time in the shake table; (b) displacement versus time in concrete slab 1; (c) displacement versus time in concrete slab 2; (d) displacement versus time in lightweight roof. 
Figure 19 reveals some interesting findings. First, a progressive increase of the longitudinal displacement with the height is observed. The measured maximum longitudinal displacements values are 2.18, 4.99, 7.15, and 8.23 milimeters for shake table, Concrete Slab 1, Concrete Slab 2, and flexible roof, respectively. The displacement shows almost a linear trend from shake table to Concrete Slab 2, while the variation is much smaller from Concrete Slab 2 to flexible roof.

Moreover, the visual inspections carried out after the seismic tests revealed that no structural damage is observed in the building (i.e., no cracks in the walls or slabs appeared and, of course, no concrete crushing occurred). This means that the seismic energy was completely dissipated by the connections, i.e., by the low-cost energy dissipation systems placed on the connections between the walls and the footings and the flexible connections between the walls and the slabs. The main aim of the research, which is the design and validation of a low-cost energy dissipation system, as well as the flexible connection between the walls and the slabs, has been reached.

At the end of the seismic event, the residual longitudinal displacements of the both concrete slabs and the flexible roofs are almost zero, which means that the building recovers its original position, that is, the walls recover their upright position.

Finally, it is concluded that the building reached the performance level of "immediate occupancy", according to ACI374.2R-13 [34].

\subsubsection{Longitudinal Accelerations of the Shake Table and the Building}

Figure 20 shows the diagrams of the longitudinal acceleration versus time during the "El Centro" earthquake at the following locations: shake table, Concrete Slab 1, Concrete Slab 2, and lightweight roof.

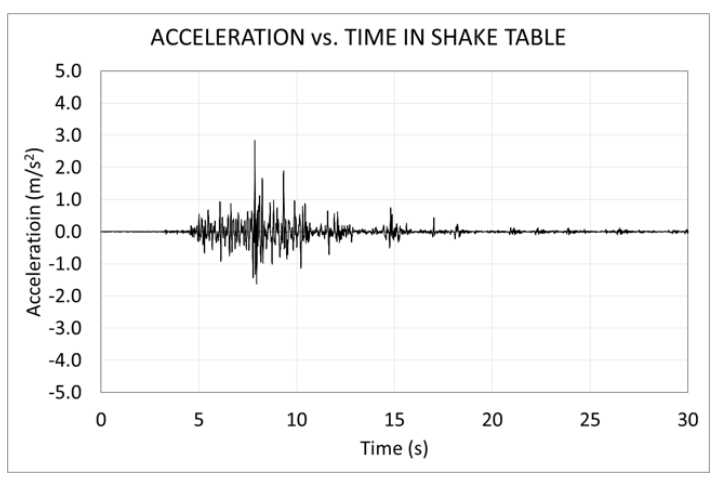

(a)

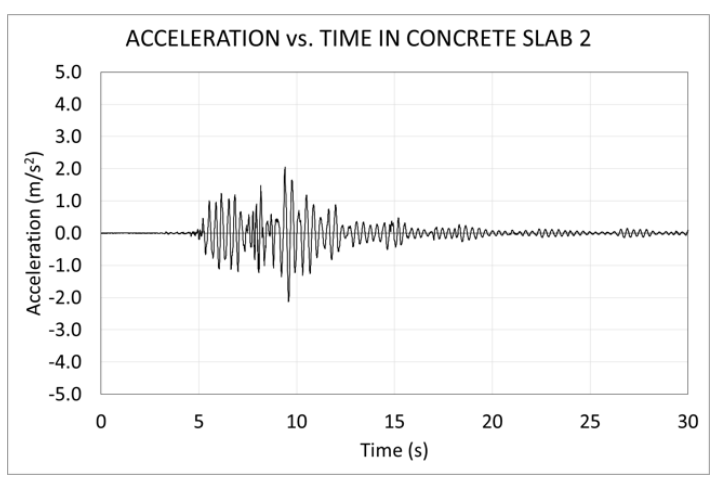

(c)

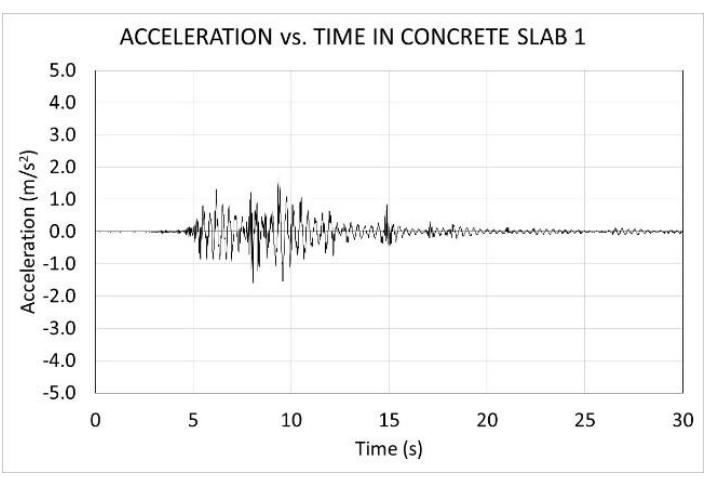

(b)

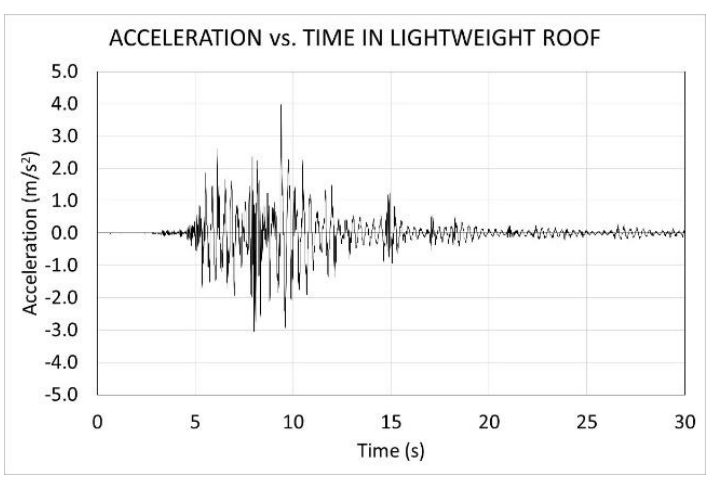

(d)

Figure 20. Diagrams of longitudinal acceleration vs. time at different locations, from shake table to lightweight roof. (a) Acceleration versus time in shake table; (b) acceleration versus time in concrete slab 1; (c) acceleration versus time in concrete slab 2; (d) acceleration versus time in lightweight roof. 
Figure 20 reveals that this structure is especially resistant to the earthquake "El Centro", since the maximum measured longitudinal accelerations of the concrete slabs is smaller than the one on the shake table. The maximum measured longitudinal acceleration at the lightweight roof is a bit larger than the one on the shake table. Specifically, the maximum measured longitudinal acceleration is $2.8 \mathrm{~m} / \mathrm{s}^{2}$ on the shake table, $1.7 \mathrm{~m} / \mathrm{s}^{2}$ on the first concrete slab, $2.1 \mathrm{~m} / \mathrm{s}^{2}$ on the second concrete slab, and $4.0 \mathrm{~m} / \mathrm{s}^{2}$ on the top of the building.

The dominant excitation frequency of the earthquake "El Centro" is around $1.6 \mathrm{~Hz}$ (Figure 21), and the natural frequency of the building is around $3.4 \mathrm{~Hz}$ before the seismic tests (Figure 22) and $2.6 \mathrm{~Hz}$ after them (Figure 23). This large difference between the excitation frequency and the natural frequency implies that the longitudinal accelerations that the earthquake causes in the building are small. Consequently, the horizontal inertial forces are also small, as well as the internal forces caused by the earthquake.

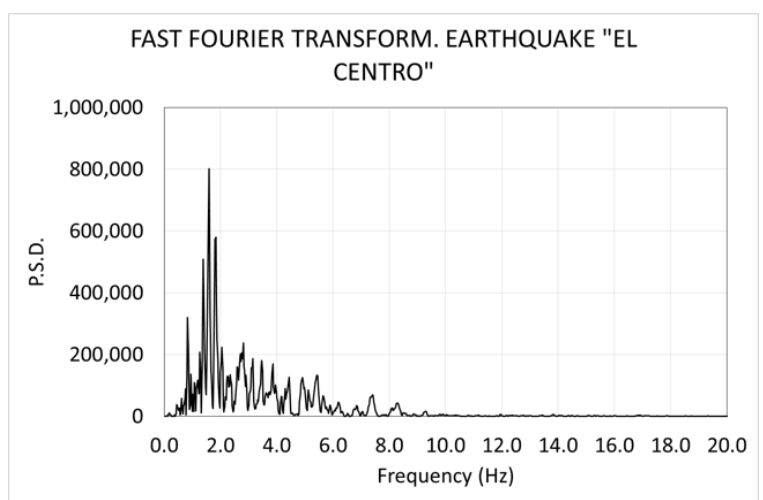

Figure 21. Dominant frequencies of earthquake "El Centro".

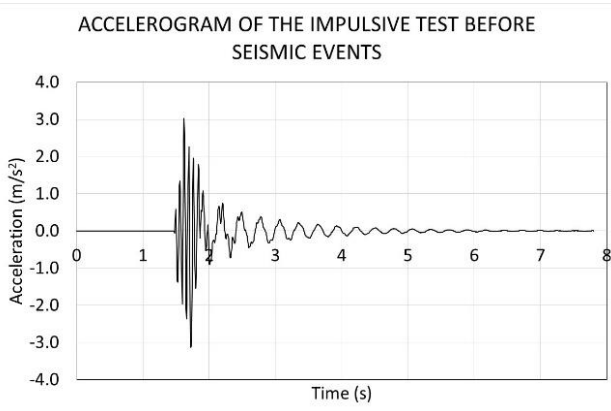

(a)

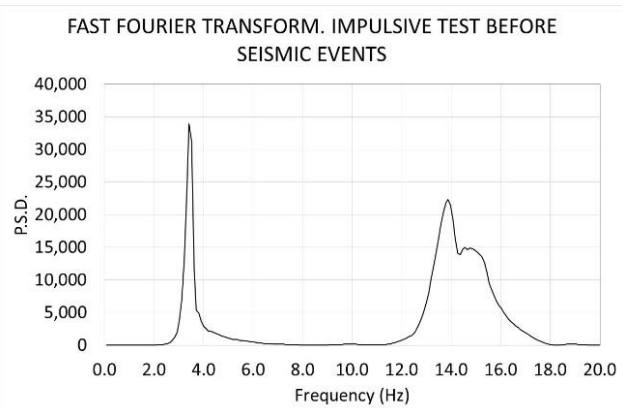

(b)

Figure 22. One-cycle impulsive test before seismic events. (a) Accelerogram; (b) fast Fourier transform.

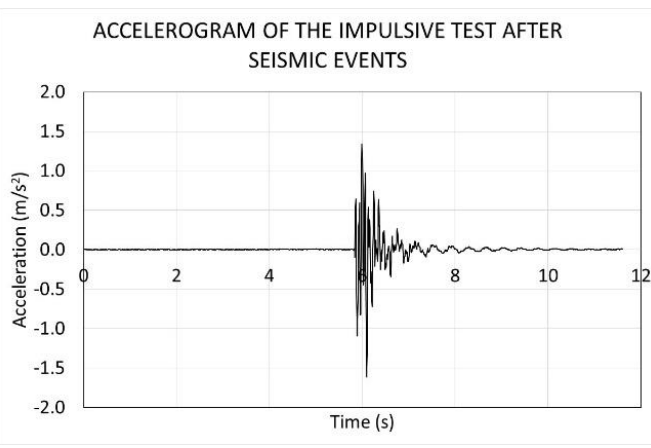

(a)

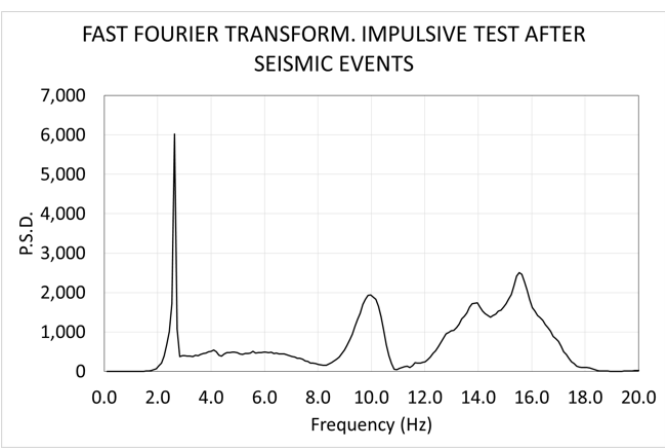

(b)

Figure 23. One-cycle impulsive test after seismic events. (a) Accelerogram; (b) fast Fourier transform. 
The seismic event results in a reduction of the natural frequency of the building by $0.8 \mathrm{~Hz}$, that is, $23 \%$. Since no concrete cracks were observed, it is concluded that the damage is completely focused on the connections, both the low-cost energy dissipation system and the flexible connections between slab and walls.

Additionally, the measured damping factor of the building is $4.7 \%$ before the seismic tests and $6.2 \%$ after them. This increase in the damping factor is also a good indicator of the damage caused by the seismic tests.

When the seismic response of the building is compared to Eurocode 8 [38], it is observed that the measured elastic response spectrum $\mathrm{S}(\mathrm{T})$, defined as the ratio between the maximum acceleration of the building and the ground acceleration (i.e., the maximum acceleration of the shake table) is 1.43, which is smaller than the theoretical S(T) provided by this European standard. This means that the standard is conservative, as expected.

Additionally, it is highlighted that the natural frequency of the structure is below $4 \mathrm{~Hz}$ before the seismic event (Figure 22b), which is the lowest threshold of the dangerous region of the "El Centro" earthquake (see Figure 10c) and no relevant accelerations are developed during the seismic events. Moreover, the loss of stiffness caused by the seismic events reduces the natural frequency (Figure 23b) of the structure and, consequently, reduces the horizontal accelerations caused by the earthquake, which prevents the structure from aftershock earthquakes.

\section{Conclusions}

This paper shows the design and the laboratory validation tests of a new low-cost energy dissipation system, for application in precast concrete structures composed of precast footings, precast structural walls, and precast concrete slabs. This energy dissipation system basically consists of a specific connection between the precast footing and the precast structural wall, formed by a set of threaded steel bars that connect both elements. During an earthquake, the steel bars undergo plastic deformation, absorbing most of the energy generated by the earthquake and preventing damage to the rest of the building. The additional advantage of this solution is that steel bars can be easily replaced after the seismic event. Additionally, a flexible connection between walls and slab has been used.

A testing campaign was carried out, including three phases. First, pushover tests were carried out on isolated structural walls formed by one precast structural wall and a precast footing. Second, pushover tests were carried out on structural frames, composed of two precast structural walls placed over two precast footings and connected to a precast slab. Thirdly, seismic tests using a shake table were carried out on a real-scale three-storey precast concrete building, consisting of two precast structural walls placed over two precast footings, two intermediate precast slabs, and a flexible steel roof.

The aim of this structural solution is to fulfill the requirements of the American standard ACI374.2R-13 [34] and more specifically, fulfill the structural performance level of "immediate occupancy", which means that the building can be used without collapse risk once the seismic event has occured.

The pushover tests on isolated structural walls revealed that this solution exhibits a linear-elastic behavior until and beyond the critical drift (which is $0.5 \%$ ) and no cracks were observed in the structures. The maximum load was reached at a drift of $3 \%$, which was six times greater than the critical drift. Beyond this drift, the structure began to show a plastic behavior. However, no structural damage was observed in the concrete elements, which means that the majority of the energy dissipated by the structural element was through the low-cost energy dissipation device. Additionally, a great ductility of the solution was observed.

The pushover tests on structural frames revealed that the flexible connection between the walls and the slab exhibited an excellent structural behavior. Again, this solution exhibited a linear-elastic behavior until and beyond the critical drift (which is $0.5 \%$ ) and no cracks were observed in the structures. The maximum load was reached at a drift of $2 \%$, which was four times greater than the critical drift. 
Beyond this drift, the structure began to show a plastic behavior. At this moment, the flexible connections worked as an asymmetrical plastic hinge, able to transmit relevant negative bending moments but almost negligible positive bending moments. This reduction in the overall horizontal stiffness of the frame resulted in an increased plastic behavior of the structure and, in consequence, an increased capacity to dissipate seismic energy. In this case, small horizontal cracks in the walls (especially in the external face of the Wall 2 where the tension strain is larger) were observed.

The seismic tests revealed an excellent behavior of the real-scale three-storey precast concrete building. The structure was subjected to a main earthquake and six foreshocks. The earthquake used was "El Centro" (the eathquake that occurred in the city of El Centro, California, USA in 1979). Additionally, two one-cycle impulsive tests were performed, one before the seismic events and the other after the seismic events, in order to measure the dynamic parameters of the building (natural frequency and damping ratio) before and after the seismic events.

The visual inspections carried out after the seismic tests revealed that no structural damage was observed in the building (i.e., no cracks in the walls or slabs appeared and, of course, no concrete crushing occurred). This means that the seismic energy was completely dissipated by the connections, i.e., by the low-cost energy dissipation systems placed on the connections between the walls and the footings and the flexible connections between the walls and the slabs.

At the end of the seismic event, the residual longitudinal displacements of the both concrete slabs and the lightweight roofs were almost zero, i.e., the building recovered its original position.

The impulsive tests revealed that the seismic events caused a decrease in the natural frequency and an increase in the damping ratio, which illustrates the damage given by the seismic tests.

Finally, it is concluded that the building reached the performance level of "immediate occupancy", according to ACI374.2R-13 [34].

Author Contributions: Design of the structural solution, J.F., D.M., and A.C.J.; design of the testing campaign, J.F., D.M., A.C.J., J.M., and M.Á.V.; development and supervision of the tests, Á.M., J.F., D.M., J.M., and D.C.G.; data interpretation, Á.M., J.F., J.M., and M.Á.V.; funding acquisition and project administration, D.M. and A.C.J.; writing, reviewing and editing the paper, Á.M. and M.Á.V. All authors have read and agreed to the published version of the manuscript.

Funding: This project has received funding from the Eurostars-2 joint programme with co-funding from the European Union Horizon 2020 research and innovation programme. The project name is "Novel Seismic-Resistant construction system composed of precast structures" (SEISMPRECAST) and the main partners are ICONKRETE 2012, S.L. and EXERGY, LTD.

Conflicts of Interest: The authors declare no conflict of interest.

\section{References}

1. Li, Y.-W.; Li, G.-Q.; Sun, F.-F.; Jiang, J. Experimental study on continuous energy-dissipative steel columns under cyclic loading. J. Const. Steel Res. 2018, 141, 104-117. [CrossRef]

2. Ismail, M. Seismic isolation of structures, Part II: A case study using the RNC isolator. HyA 2018, 69, 177-195. [CrossRef]

3. Lobo, P.S.; Almeida, J.; Guerreiro, L. Recentring and control of peak displacements of a RC frame using damping devices. Soil Dyn. Earth. Eng. 2017, 94, 66-74. [CrossRef]

4. Kramer, A.; Barbosa, A.R.; Sinha, A. Performance of Steel Energy Dissipators Connected to Cross-Laminated Timber Wall Panels Subjected to Tension and Cyclic Loading. J. Struct. Eng. 2016, 142, E4015013. [CrossRef]

5. Sorace, S.; Terenzi, G.; Mori, C. Passive energy dissipation-based retrofit strategies for R/C frame water towers. Eng. Struct. 2016, 106, 385-398. [CrossRef]

6. López-Almansa, F.; Segués, E.; Cantalapiedra, I.R. A new steel framing system for seismic protection of timber platform frame buildings. Implementation with hysteretic energy dissipators. Earthq. Eng. Struct. Dyn. 2015, 44, 1181-1202. [CrossRef]

7. Beziat, A.; Mora, A.; Chase, J.G.; MacRae, G.A.; Rodgers, G.W.; Clifton, C. Performance Analysis of Energy Dissipators and Isolators Placed in Bridges to Prevent Structural Damage in Columns. J. Earthq. Eng. 2012, 16, 1113-1131. [CrossRef] 
8. López, A.; de la Cruz, S.T.; Taylor, C. Experimental study of friction dissipators for seismic protection of building structures. Earthq. Eng. Eng. Vib. 2011, 10, 475-486. [CrossRef]

9. Symans, M.D.; Charney, F.A.; Whittaker, A.S.; Constantinou, M.C. Energy Dissipation Systems for Seismic Applications: Current Practice and Recent Developments. J. Struc. Eng. 2008, 134, 3-21. [CrossRef]

10. Sassu, M. The reinforced cut wall (RCW): A low-cost base dissipator for masonry buildings. Earthq. Spectra 2006, 22, 533-554. [CrossRef]

11. Peng, P.; LiePing, Y.; Wei, S.; HaiYun, C. Engineering practice of seismic isolation and energy dissipation structures in China. Sci. Ch. Tech. Sci. 2012. [CrossRef]

12. Ismail, M. Seismic isolation of structures. Part I: Concept, review and a recent development. HyA 2018, 69, 147-161. [CrossRef]

13. Villaverde, R. Methods to Assess the Seismic Collapse Capacity of Building Structures: State of the Art. J. Struct. Eng. 2007, 133, 57-66. [CrossRef]

14. Zhanyu, B.; Jian, G.; Rongyue, Z.; Jianwei, S.; Lee, G.C. Cyclic performance and simplifi ed pushover analyses of precast segmental concrete bridge columns with circular section. Earthq. Eng. Eng. Vib. 2016, 15, $297-312$.

15. Jiang, L.; Zheng, H.; Hu, Y. Seismic behaviour of a steel frame partially infilled with precast reinforced concrete wall. Adv. Struct. Eng. 2016, 19, 1637-1649. [CrossRef]

16. Ou, Y.-C.; Tsai, M.-S.; Oktavianus, Y.; Chang, K.-C. Cyclic testing of a large tall precast segmental concrete bridge column with a cast-in-place plastic hinge region. Earthq. Spectra 2013, 29, 1441-1457. [CrossRef]

17. Di Sarno, L.; Manfredi, G. Experimental tests on full-scale RC unretrofitted frame and retrofitted with buckling-restrained braces. Earthq. Eng. Struct. Dyn. 2012, 41, 315-333. [CrossRef]

18. Guner, S.; Vecchio, F.J. Analysis of Shear-Critical Reinforced Concrete Plane Frame Elements under Cyclic Loading. J. Struct. Eng. 2011, 137, 834-843. [CrossRef]

19. Ou, Y.-C.; Tsai, M.-S.; Chang, K.-C.; Lee, G.C. Cyclic behavior of precast segmental concrete bridge columns with high performance or conventional steel reinforcing bars as energy dissipation bars. Earthq. Eng. Struct. Dyn. 2010, 39, 1181-1198. [CrossRef]

20. Braconi, A.; Bursi, O.S.; Fabbrocino, G.; Salvatore, W.; Taucer, F.; Tremblay, R. Seismic performance of a 3D full-scale high-ductile steel-concrete composite moment-resisting frame-Part II: Test results and analytical validation. Earthq. Eng. Struct. Dyn. 2008, 37, 1635-1655. [CrossRef]

21. Maheri, M.R.; Kousari, R.; Razazan, M. Pushover tests on steel X-braced and knee-braced RC frames. Eng. Struct. 2003, 25, 1697-1705. [CrossRef]

22. Wenfeng, L.; Tao, W.; Xi, C.; Xiang, Z.; Peng, P. Pseudo-dynamic tests on masonry residential buildings seismically retrofi tted by precast steel reinforced concrete walls. Earthq. Eng. Eng. Vib. 2017, 16, 587-597.

23. Socuoglu, H.; Lin, W.-H.W.; Binici, B.; Ezzatfar, P. Pseudo-Dynamic Testing, Performance Assessment, and Modeling of Deficient Reinforced Concrete Frames. ACI Struct. J. 2014, 111, 1203-1212.

24. Brun, M.; Labbe, P.; Bertrand, D.; Courtois, A. Pseudo-dynamic tests on low-rise shear walls and simplified model based on the structural frequency drift. Eng. Struct. 2011, 33, 796-812. [CrossRef]

25. Donea, J.; Jones, P.M.; Magonette, G.E.; Verzeletti, G. The Pseudo-dynamic test method. In Recent Advances in Earthquake Engineering and Structural Dynamics; Davidovici, V.E., Ed.; Ouest Editions: Nantes, France, 1992; pp. 769-780.

26. Benavent-Climent, A.; Galé-Lamuela, D.; Donaire-Avila, J. Energy capacity and seismic performance of RC waffle-flat plate structures under two components of far-field ground motions: Shake table tests. Earthq. Eng. Struct Dyn. 2019, 48, 949-969. [CrossRef]

27. Li, C.; Bi, K.; Hao, H. Seismic performances of precast segmental column under bidirectional earthquake motions: Shake table test and numerical evaluation. Eng. Struct. 2019, 187, 314-328. [CrossRef]

28. Gavridou, S.; Wallace, J.W.; Nagae, T.; Matsumori, T.; Tahara, K.; Fukuyama, K. Shake-Table Test of a Full-Scale 4-Story Precast Concrete Building. I: Overview and Experimental Results. J. Struct. Eng. 2017, 143. [CrossRef]

29. Chen, M.C.; Pantoli, E.; Wang, X.; Astroza, R.; Ebrahimian, H.; Hutchinson, T.C.; Conte, J.P.; Restrepo, J.I.; Marin, C.; Walsh, K.D.; et al. Full-scale structural and nonstructural building system performance during earthquakes. I: Specimen description, test protocol and structural response. Earthq. Spectra 2016, 32, 737-770. [CrossRef]

30. Onat, O.; Lourenço, P.B.; Koçak, A. Experimental and numerical analysis of RC structure with two leaf cavity wall subjected to shake table. Struct. Eng. Mech. 2015, 55, 1037-1053. [CrossRef] 
31. Nagae, T.; Ghannoum, W.M.; Kwon, J.; Tahara, K.; Fukuyama, K.; Matsumori, T.; Shiohara, H.; Kabeyasawa, T.; Kono, S.; Nishiyama, M.; et al. Design Implications of Large-Scale Shake-Table Test on Four-Story Reinforced Concrete Building. ACI Struct. J. 2015, 112, 135-146.

32. Panagiotou, M.; Restrepo, J.I.; Conte, J.P. Shake-Table Test of a Full-Scale 7-Story Building Slice. Phase I: Rectangular Wall. J. Struct. Eng. 2011, 137, 691-704. [CrossRef]

33. Lee, H.-S.; Woo, S.-W. Seismic performance of a 3-story RC frame in a low-seismicity region. Eng. Struct. 2002, 24, 719-734. [CrossRef]

34. American Concrete Institute Committee 374. ACI374.2R-13: Guide for Testing Reinforced Concrete Structural Elements under Slowly Applied Simulated Seismic Loads; ACI: Farmington Hills, MI, USA, 2013.

35. European Committee for Standardization. Eurocode 2, Design of Concrete Structures; European Committee for Standardization: Brussels, Belgium, 2004.

36. European Committee for Standardization. Testing Hardened Concrete-Part 3: Compressive Strength of Test Specimens; EN 12390-3; European Committee for Standardization: Brussels, Belgium, 2009.

37. International Organization for Standardization. ISO 898-1:2013, Mechanical Properties of Fasteners Made of Carbon Steel and Alloy Steel. Part 1: Bolts, Screws and Studs with Specified Property Classes-Coarse Thread and Fine Pitch Thread; ISO: Geneva, Switzerland, 2013.

38. European Committee for Standardization. Eurocode 8: Design of Structures for Earthquake Resistance-Part 1: General Rules, Seismic Actions and Rules for Buildings; European Committee for Standardization: Brussels, Belgium, 2009.

(C) 2020 by the authors. Licensee MDPI, Basel, Switzerland. This article is an open access article distributed under the terms and conditions of the Creative Commons Attribution (CC BY) license (http://creativecommons.org/licenses/by/4.0/). 